\title{
Mercury, Cadmium Content and Organoleptic Quality of Some Canned Seafood Sold In Nigerian Market
}

\author{
*A.F. Babalola, A.O. Olusola, G.R. Akande, M.O. Ezekiel,T. A. Adeleke, \\ P.A. Ozor. \\ Fish technology/Biotechnology Department, Nigerian Institute for Oceanography and Marine Research, \\ Victoria Island, Lagos State.
}

\begin{abstract}
In this study, two heavy metals in canned seafood were determined after digestion by the Association of Official Analytical Chemists methods. Mercury and Cadmium levels in this canned seafood were determined by flame atomic absorption photometry. The results of this study indicate that the canned seafood imported into the country have concentrations well below the permissible EU levels for these toxic metals. Their contribution to the body burden can therefore be considered negligible and the canned seafood products seem to be safe for human consumption. For the organoleptic quality, tuna flakes in vegetable oil (Starkist) from Ghana, tuna chunks in sunflower oil (John West) from UK, sardines in vegetable oil (Titus) and mackerel in tomato sauce (Toma) both from Morocco were the most preferred while the least preferred were light tuna chunks in oil (Bumble Bee) from USA and tuna flakes in brine (John West) from Thailand.
\end{abstract}

Keywords:Mercury, cadmium, canned seafood, organoleptic quality.

\section{Introduction}

There is increasing concern about the quality of foods in several parts of the world. The determination of toxic elements in food has prompted studies on toxicological effects of them in food. Heavy metals are considered the most important form of pollution of the aquatic environment because of their toxicity and accumulation by marine organisms. While mercury and cadmium can be tolerated at extremely low levels, at certain concentrations, they are exceptionally toxic to humans.

Methyl mercury may induce alterations in the normal development of the brain of infants and at higher levels may induce neurological changes in adults. Mercury contaminates mostly fish and fishery products. Cadmium accumulates in the human body and may induce kidney dysfunction, skeletal damage and reproductive deficiencies. Also, it cannot be excluded that it acts as a human carcinogen (Council Regulation [EC] 2001).

Metal pollution of the sea is less visible and direct than other types of marine pollution but its effects on marine ecosystems and humans are intense and very extensive. The toxic effects of heavy metals, particularly arsenic, mercury, cadmium and lead, have been broadly studied(Inskip and Piotrowsiki, 1985;Kurieshy and D'siliva1993;Narvaez, 2002;Nishihara, et. al., 1985).

The distribution of metals varies between fish species, depending on age, development status and other physiological factors (Kagi and Schaffer, 1998). Fish accumulate substantial concentrations of mercury in their tissues and thus can represent a major source of this element for humans. Fish are the single largest sources of mercury and cadmium for man. Mercury is a known human toxicant and the primary sources of mercury contamination in man are through eating fish. Biotransformation of mercury and methyl mercury formation constitutes a dangerous problem for human health (Inskip and Piotrowsiki, 1985).

Metal contaminations in food, especially in marine products, have been broadly investigated (Enomoto and Uchida 1973; Uysal, 1980;Liang, et. al., 1999). Tuna as a predator is able to concentrate large amount of heavy metals. Some of the metals are used for biomonitoring of environmental contamination (Enomoto and Uchida, 1973; Schmitt and Brumbaugh, 1990). Nigeria is a large consumer of canned fish imported into the country from EU, Asia countries and USA.

The present study was carried out to determine the current levels of total mercury and cadmium in canned seafood imported in Nigeria, with the purpose of ascertaining whether the concentrations would exceed the maximum level of safety recommended by European Commission decision (Council Regulation [EC], 2001)and WHO(World Health Organisation). Organoleptic assessment was carried out to determine the preference pattern of the fishery product.

\section{Materials and Methods}

Sample collection: Twenty canned fish and fishery products samples imported from different countries were obtained from the retail market (Shoprite in Victoria Island, Lagos). They include: Tuna flakes in vegetable oil, 
Light tuna chunks in oil, Skipjack tuna salad, Tuna in mayonnaise, Tuna steak in sunflower oil, Tuna steak in brine, Tuna flakes in sunflower oil, Tuna flakes in brine, Tuna chunks in sunflower in oil, Tuna chunks in brine, Mackerel in tomato sauce (Geisha), Mackerel in tomato sauce (Toma), Sardines in vegetable oil, Portuguese sardines in sunflower oil, Princes sardines in tomato sauce, Gomes da costa sardines in tomato sauce, Boneless sardines in sunflower oil, Pescamar sardines in tomato sauce, Prawns in brine and Shrimps in brine.

Apparatus and reagents: All glassware was soaked overnight in 10\% (v/v) nitric acid followed by washing with $10 \%(\mathrm{v} / \mathrm{v})$ hydrochloric acid rinsed with double distilled water and dried before using. A Perkin Elmer Analyst 100 atomic absorption spectrophotometer equipped with a deuterium background corrector was used for the determination of heavy metals. All reagents used were of analytical grade.

Sample preparation and digestion: After opening each can, oil was drained off and the meat was homogenized thoroughly in a 2-speed (low/high); 1 litre stainless steel Warring 7011s Lab blender. Samples were then taken and digested promptly as follows:2g of homogenized sample was weighed and placed into a $150 \mathrm{ml}$ conical flask. To this was added $5 \mathrm{ml}$ concentrated sulphuric acid, and then heated for $2 \mathrm{hr}$. (or until the sample was completely digested). The mixture was cooled and $25 \mathrm{ml}$ of $6 \%$ potassium permanganate solution was added to the cooled solution. The mixture was heated at $70^{\circ} \mathrm{C}$ for $2 \mathrm{hr}$, and then cooled. 10 ml hydroxyl ammonium chloride was added to the solution, to reduce excess permanganate. The mixture was then diluted to $50 \mathrm{ml}$ in a volumetric flask, with distilled water. A blank (distilled water) solution was taken through the same process. $5 \mathrm{ml}$ of $1000 \mathrm{mg} / \mathrm{l}$ stock standard was diluted to $200 \mathrm{ml}$ to give $25 \mathrm{mg} / \mathrm{l}$ intermediate stock standard. From this, three working standards were prepared in the range $0.001-0.005 \mathrm{mg} / \mathrm{l}$. Mercury and cadmium was determined by direct aspiration of the sample solution into the $\mathrm{NO}_{2}$ /acetylene flame. The blanks and calibration standard solutions were also analysed in the same way as the sample solutions.

Organoleptic assessment: Subjective evaluation of each product sample was carried out in accordance with Post et al (1991), bytrained panellist of ten. Coded samples accompanied by questionnaires were presented to the panellist. The samples were scored for appearance, flavour, taste and texture using a 4-point scale in which a score of 4 was given to the excellent product and 1 to the sample that was fair. Statistical analysis was also carried out to determine the difference between the samples that was preferred.

\section{Results and Discussion}

Results presented in Table 1 indicate that the assayed canned seafood had concentrations of mercury and cadmium well below the permissible EU levels for these toxic metals $(0.5 \mathrm{mg} / \mathrm{kg}$ and $0.3 \mathrm{mg} / \mathrm{kg}$ for mercury and cadmium respectively), their contribution to the body burden can therefore be considered negligible and the fish seem to be safe for human consumption.

The result of the organoleptic assessment as reported in Figure 1, showed that tuna flakes in vegetable oil (Starkist) from Ghana, tuna chunks in sunflower oil (John West) from UK, sardines in vegetable oil (Titus) and mackerel in tomato sauce (Toma) both from Morocco were the most preferred while the least preferred were light tuna chunks in oil (Bumble Bee) from USA and tuna flakes in brine (John West) from Thailand.

There is a dearth of data for this research in Nigeria. Meanwhile, the data generated in the present study compared well with similar studies carried out in different parts of the world.

The consumption of fish, seafood and their derived products is the main pathway to human exposure to heavy metals. The levels of toxic elements in shellfish are related to age, sex, season and place (Kagi and Schaffer, 1998).It is also reported that cooking reduces the amount of some metals (Atta, et. el., 1997).The process of canning involves Pre-cooking and Sterilization. Moreover, the advances of new packaging technology, especially the use of cans with lacquered walls and mechanical seam, reduce or, in most cases, eliminate the leaching of heavy metals into the food. It is also safe to say that the waters where these canned Tuna products were caught must be relatively free of industrial pollution.

Fish and seafood products are the main protein diets. They are very delicious and useful for health and they have many consumers throughout the world. Therefore they must be safe for human consumption. 
Table 1: Mercury and Cadmium content of some imported canned seafood

\begin{tabular}{|c|c|c|c|}
\hline $\mathrm{S} / \mathrm{N}$ & Canned fish and fishery products & $\begin{array}{l}\text { Mercury } \\
\mathrm{mg} / \mathrm{kg}\end{array}$ & $\begin{array}{l}\text { Cadmium } \\
\mathrm{mg} / \mathrm{kg}\end{array}$ \\
\hline 1. & Tuna Flakes in Vegetable Oil (Starkist) from Ghana & n.d & n.d \\
\hline 2. & Light Tuna Chunks in Oil (Bumble Bee) from USA & n.d & n.d \\
\hline 3. & Skipjack Tuna Salad (John West) from Thailand & n.d & n.d \\
\hline 4. & Tuna in Mayonnaise (John West) from Thaialand & n.d & n.d \\
\hline 5. & Tuna Steak in Sunflower Oil (John West) from UK & n.d & n.d \\
\hline 6. & Tuna Steak in Brine (John West) from UK & n.d & n.d \\
\hline 7. & Tuna Flakes in Sunflower Oil (John West) from Thailand & n.d & n.d \\
\hline 8. & Tuna Flakes in Brine (John West) from Thailand & n.d & n.d \\
\hline 9. & Tuna Chunks in Sunflower Oil (John West) from Thailand & n.d & n.d \\
\hline 10. & Tuna Chunks in Brine (John West) from Thailand & n.d & n.d \\
\hline 11. & Mackerel in tomato sauce (Geisha) from Morocco & n.d & 0.028 \\
\hline 12. & Mackerel in tomato sauce (Toma) from Morocco & n.d & 0.001 \\
\hline 13. & Sardines in vegetable oil (Titus) from Morocco & n.d & 0.001 \\
\hline 14. & Portuguese sardines in sunflower oil from Portugal & n.d & 0.001 \\
\hline 15. & Princes sardines in tomato sauce from Morocco & n.d & 0.012 \\
\hline 16. & Gomes da Costa sardines in tomato sauce from Argentina & n.d & 0.001 \\
\hline 17. & Boneless sardines in sunflower oil (John West) from UK & n.d & 0.010 \\
\hline 18. & Pescamar sardines in tomato sauce from South Africa & n.d & 0.025 \\
\hline 19. & Prawns in brine (John West) from Vietnam & n.d & 0.001 \\
\hline 20. & Shrimps in brine (John West) from Vietnam & n.d & 0.001 \\
\hline
\end{tabular}

\section{n.d $=$ not detected}

Note:

EU Permitted levels for Mercury in canned tuna fish $=0.5 \mathrm{mg} / \mathrm{kg}$

EU Permitted levels for Cadmium in canned tuna fish $=0.3 \mathrm{mg} / \mathrm{kg}$

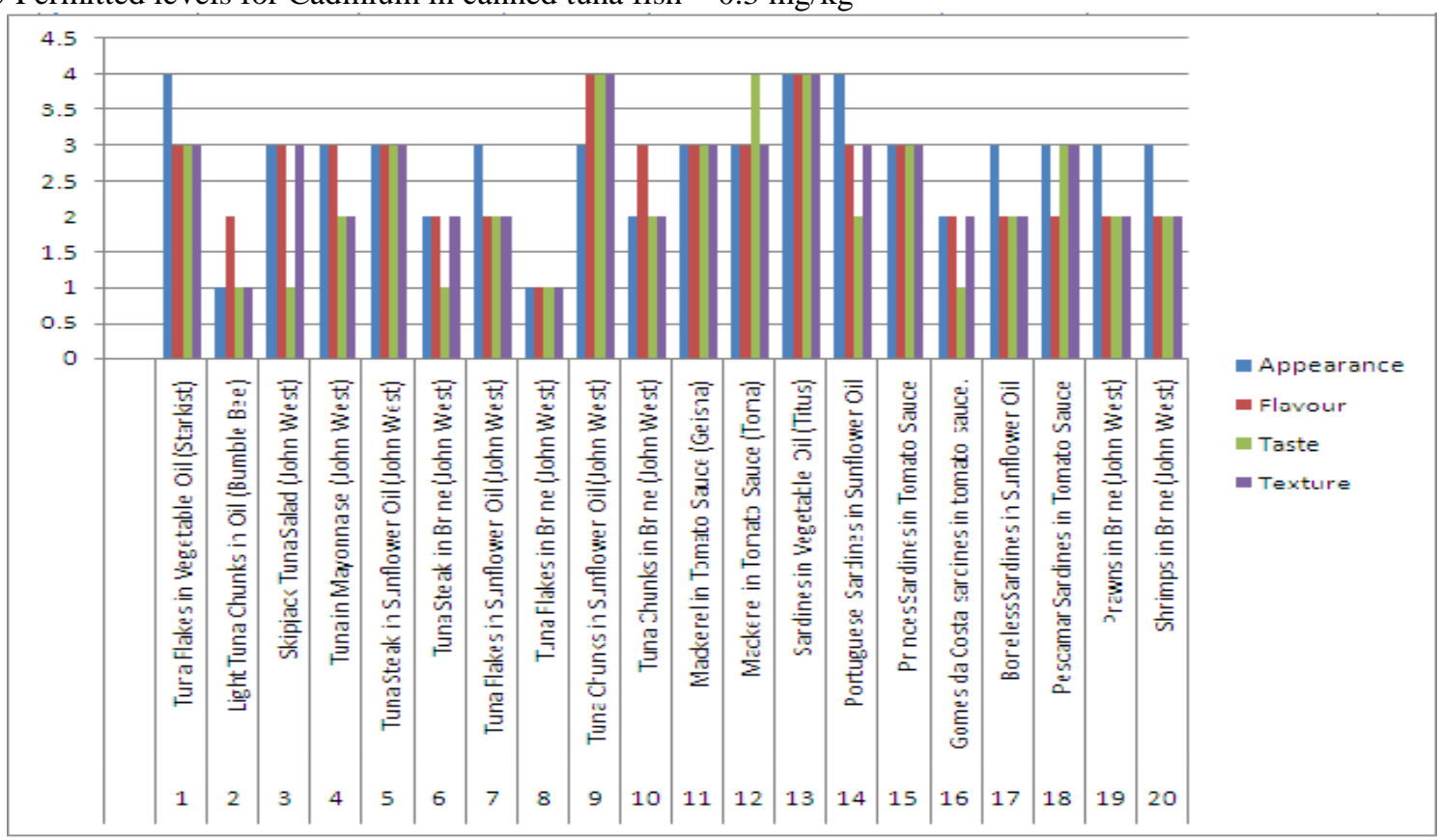

Fig 1: Organoleptic quality of some imported canned seafood

Note:

$4=$ Excellent

$3=$ Good

2 = Satisfactory

$1=$ Fair

\section{Conclusion}

The study presented data on the levels of some heavy metals in canned seafood collected from retail markets in Victoria Island, Lagos, Nigeria. These canned seafood samples are representative for the market by its variability. 
Though estimates of the amount of toxic metals consumed in the diet are difficult to obtain and a discussion of heavy metal tolerances in the diet is beyond this paper, it can be concluded from the results so far obtained that mercury and cadmium contents of canned seafood imported into Nigeria is unlikely to constitute a significant health hazard.

\section{Acknowledgements}

We acknowledge The Director of Fish Tech/Biotech Department, Nigerian Institute for Oceanography and Marine Research, for his technical support and NIOMR for the funding of the project.

\section{References}

[1]. Atta, M.B., El-Sebaie, L.A., Noaman, M.A., \&Kassab, H.E. (1997). The effect of cooking on the content of heavy metals in fish. Food Chemistry, 58, 1-4.

[2]. Council Regulation [EC] No 466/2001 of 8 March 2001 setting maximum levels for certain contaminants in foodstuffs (Official Journal L 313, 30/11/2001 P. 0060-0060).

[3]. Enomoto, N., \& Uchida, Y. (1973). Cadmium and other heavy metals contents in marine products from Ariak Sea in canned goods in the market. Saga daigakuNogakuInho, 69-75, [cited in Chem. Abstr. 18 (1974) 2506].

[4]. Inskip, M.J., \&Piotrowsiki, J.K. (1985). Review of the health effects of methyl mercury. Journal of Applied Toxicology, 5, $113-133$.

[5]. Kagi, J.H., \& Schaffer, A. (1998). Biochemistry of metallothionein. Biochemistry, 27, 8509-8515.

[6]. Kurieshy, T.W., \&D'siliva, C. (1993). Uptake and loss of mercury, cadmium and lead in marine organisms. Indian Journal of Experimental Biology, 31, 373-379.

[7]. Liang, Y., Cheung, R.Y.H., \& Wong, M.H. (1999). Reclamation of wastewater for polyculture of freshwater of freshwater fish, bioaccumulation of trace metals in fish. Water Research, 33, 2690-2700.

[8]. Narvaez, D.M. (2002).Human exposure to mercury in fish mining areas in the Philippines. FAO/WHO Global forum of food safety regulation. Morocco: Marrakech.

[9]. Nishihara, T., Shimamato, T., Wen, K.C., \& Kondo, M. (1985). Accumulation of lead, cadmium and chromium in several organs and tissues of carp. Journal Hygienic Chemistry, 31, 119-123.

[10]. Schmitt, C.J., \&Brumbaugh, W.G. (1990). National contamination biomonotoring program: Concentrations of arsenic, cadmium, copper, lead, mercury, selenium and zinc in US freshwater fish, 1976-1984. Archives of Environmental Contamination and Toxicology, 19, 731-747.

[11]. Uysal, H. (1980). Levels of trace elements in some food chain organisms from the Aegean Coasts. Journess Etudes Pollution, 503512.

[12]. Post, L.M. Mackie, D.A. and Butler, G. (1991). Laboratory methods for sensory analysis of food Ottawa Research Branch Agriculture, Canada publication, 90pp. 